Norris Brock

Johnson

University of

Michigan

\title{
On the Relationship of Anthropology To Multicultural Teaching and Learning
}

To be valued and preserved, the unique characteristic of being similar yet different is the genius of being human.

Culture is best conceived as the learned, shared, and symbolic patterns of thinking, feeling, believing, and behaving on which all human beings, as distinct from other animals, rely as their primary means of survival.
"What is it, what does it mean, to be a human being?" "Why are human beings similar yet so different?" In one fashion or another, most academic disciplines study human beings and their works. Uniquely, anthropology provides a synthetic viewpoint, a panoramic perspective, a particular way of looking at, of conceiving and approaching, the condition of being human. After the fact of being human, other disciplines study human beings. The anthropological quest is for knowledge and understanding of the condition of being human.

Anthropology is the systematic, comparative study of human similarity and difference as it has developed and been expressed, throughout corresponding time and space, on the planet Earth. Scientifically, anthropology places emphasis upon the generation of testable explanatory statements or laws, accounting for regularities in patterns of human similarity and difference. Humanistically, anthropology places emphasis upon the qualities, value, and essential meaning of human experience. Serving as a timeless mirror for humankind, anthropology reflects our gloriously infinite variety and essential unity. To be valued and preserved, the unique characteristic of being similar yet different is the genius of being human.

As homo sapiens, human animals share similar needs, biology, and history. The study of anthropology reveals "alien" cultures to be groups of people solving persistent human problems in unique ways. The proper study of anthropology fosters recognition and acceptance of the essential unity of humankind. As homo sapiens, human animals share a planet comprised of radically differing environments. Human appearance (phenotype) differs primarily as an adaptative response to environment. Being human is a continually unfolding drama of reciprocal interaction between biology, environment, and culture. The proper study of anthropology fosters recognition and tolerance, if not acceptance, of human difference.

The perspective from anthropology provides valuable insights, information, and a unique approach to the more persistent problems of our own time and place. This article illustrates the importance of anthropology to the multicultural approach to education. The

Norris Brock Johnson is Adjunct Visiting Assistant Professor of Anthropology at the University of Michigan and Research Associate, Center for New Schools, Chicago, Illinois relationship between anthropology and multicultural education (here, broadly, human teaching and learning) is both reciprocal and intimate. Data, concepts, focus, methodology, and basic concerns involve each other. Both anthropology, in general, and its component subdisciplines, in particular, provide essential contributions to multicultural teaching and learning.

\section{Cultural Anthropology}

Anthropology's view suggests that being human means satisfying imperatives of biology and environment primarily through learned (cultural) rather than neurochemical (instinctual) mechanisms. To learn, rather than to involuntarily respond, is to be human; to be human is to learn.

Cultural anthropology is concerned with the nature and character of cultural similarity and difference. For our purposes, culture is best conceived as the learned, shared, and symbolic patterns of thinking, feeling, believing, and behaving on which all human beings, as distinct from other animals, rely as their primary means of survival. A culture is a distinctive way of interpreting human culture. A uniquely anthropological concept, culture is fundamental to multicultural teaching and learning.

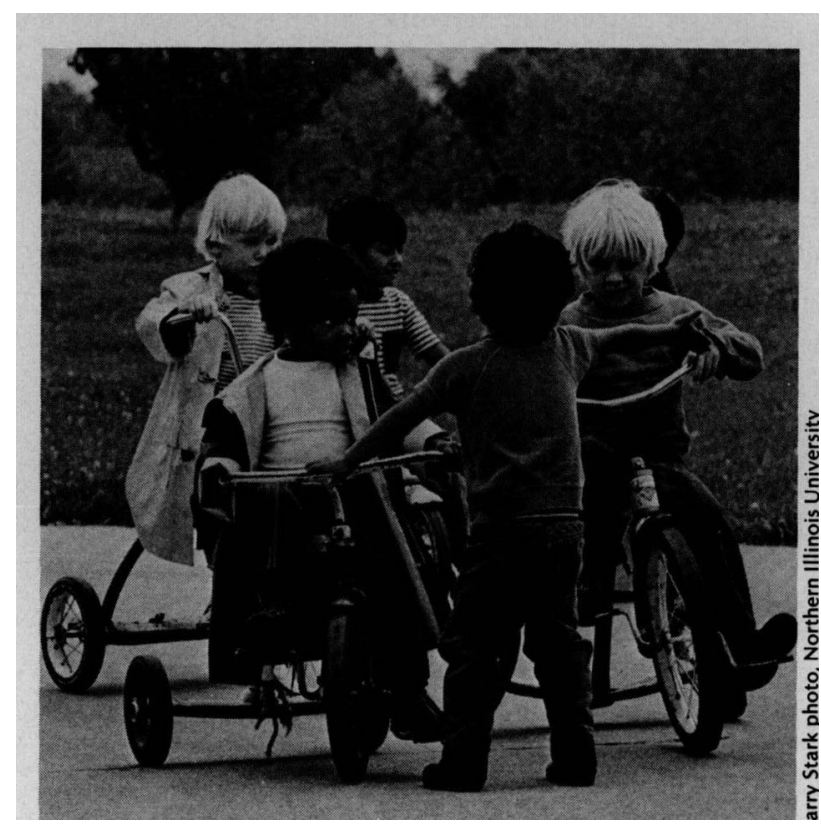


Cultural anthropologists study human teaching and learning within the context of the cultural meanings given to stages in the human life cycle. Enculturation is the lifelong process of teaching and learning a specific culture. Every culture gives different meaning to birth, childhood, adolescence, adulthood, old age, and even death. Further, if culture is learned behavior, then we ought to be aware of the varied peoples, places, situations, things, and environments that teach culture. At some point, every human being is both teacher and learner. Potentially, anything one human being culturally learns can be learned by any other human being. How, when, where, and why something is taught or learned is culturally conditioned. Every culture or subculture gives unique emphasis and style to the human requirements for teaching and learning. As concerns data on various cultural styles and meanings of teaching and learning, cultural anthropology has much to share with multicultural education.

In arguing that each culture is but a different way of being human, cultural anthropology acts to reduce racism, cultural chauvinism, and misplaced ethnocentricism. Anthropological interest in schooling is not new. For the last 20 years, cultural anthropologists have been extensively involved in public school curriculum development (Dynneson, 1975; Dwyer-Shick, 1976). As the multicultural nature of our society and the intercultural nature of our world grows self-evident, cultural anthropology will be necessary to a proper education for the future. The study of cultural anthropology itself is a multicultural education.

\section{Ethnography and Ethnology}

Ethnographic anthropology is the descriptive study and analysis of existing human cultures. Ours is a small planet saturated with thousands of cultures; thousands of ways of being human.

In their research strategies, ethnographers insist upon the direct observation of human activity; rather than laboratory experimentalism, a natural science empiricism is stressed (Williams, 1967). Spending a year or more living with the people under study, the ethnographer seeks to understand and to describe that culture as a total way of life. Traditionally working in rather small groups, ethnographers seek to record salient cultural elements as they relate, each to the other, in patterned ways. This comparative methodology and wholistic perspective is reflected in every anthropological subdiscipline. Comparisons assume the interrelatedness of systemic elements not fully defined in isolation. To "understand" a culture or subculture means to see it as a whole. Anthropological comparisons are made both within and between cultures. When separate studies (ethnographies) are compared, the ethnographer becomes an ethnologist. Ethnology is the cross-cultural comparative study of cultures. In recording varieties of human cultures, ethnography provides the empirical information for ethnological analysis. Both ethnography and ethnology have significant implications for a more effective multicultural teaching and learning.

\section{Ethnology}

The comparative study of cultures contributes a fresh perspective to concepts central to multicultural teaching and learning; specifically, the concepts of cultural pluralism and the plural society.

Cultural pluralism is a concept developed in the context of European administration of heterogeneous, complex societies; principally, in Burma, Ceylon (Sri Lanka), and the Caribbean. Created through colonial intervention, plural societies are characterized by heterogeneous populations drawn together for politioeconomic, not cultural, reasons. Plural societies have a characteristic intermix of differing "races" and cultural systems. Plural societies are characterized by social, spacial, normative, cultural, and institutional stratification and isolation. Plural societies do not evolve through collective effort and sociocultural concensus; plural societies are the byproduct of conquest. Pluralism is colonialistic and exploitative. Plural societies are neither integrative, representative, participatory, nor democratic. The concept of pluralism is as much sociopolitical and historical as it is cultural. Multiculturalism implies a process through which a person develops competence in several cultures. Pluralism implies limited cultural interaction and sharing. Ethnological anthropology suggests that education might strive for a multicultural rather than pluralistic society and culture.

Plural societies are characterized by structurally subordinate subgroups or subcultures exhibiting differential patterns of access to strategic and culturally valued resources. As concerns its component subgroups, the plural society assumes a separate-yetunequal stance. This notion of subculture undergirds the multicultural approach to education. Within the United States, the educational anthropologist John Ogbu (1974) distinguishes immigrant from subordinate minorities. Characteristically, immigrant minorities, such as Italians or Germans, are historically and linguistically part of a continential, European tradition; vis-a-vis Anglo superordinates, immigrant minorities become "White" ethnics. Comparatively, ethnic social status and degree of sociocultural access is based more on culture and history than on "race." Multiethnic teaching and learning becomes the comparative, sociological study of differing sociohistorical aspects of an encompassing European tradition. Such subordinate minorities as Native and African-Americans are characterized by a comparatively fixed social status, rank, and degree of sociocultural access as based on culture, behavior, language, and "race." A multicultural education focuses on non-European cultural traditions and histories. Inherently, multicultural teaching and learning is cross-cultural and anthropological.
To "understand" a culture or subculture means to see it as a whole.

Multiculturalism implies a process through which a person develops competence in several cultures.

Pluralism implies limited cultural interaction and sharing. 
The more

heterogeneous and complex the culture the less a

prototypic

representative of

that culture exists.
Popularly, it is assumed that individuals have only a single cultural orientation. However, and especially within heterogeneous societies, ethnological material suggests that it is possible, if not normal, for individuals to participate in and to understand several cultures (Goodenough, 1976). Multicultural competence is not assimilation; being multicultural does not require the dropping of one's parent culture. The experience of living in a complex, heterogeneous national and international society assumes multiculturalism. The more heterogeneous and complex the culture, the less a prototypic representative of that culture exists.

Most Americans have overlapping and often competing cultural identities and loyalties. Multicultural teaching and learning must resist the popular tendency of conceiving cultures and subcultures as pristine entities: fixed, unchanging, and archetypic. There is no "Indian" culture; at present, there are only various individual Americans who have Onondaga or Hopi parent cultural orientations. One is not so much "Indian"American as Hopi-American. For both the cultural anthropologist and the multicultural teacher, an overemphasis on surface custom promotes stereotyping. An exclusive focus on "stoicism" or powwows or teepees or tomahawks tends to freeze individuals into a rigid, monocultural image - an image that does not change. From both within and without, a Sioux or Ute wanting to become a corporate banker might be accused of "not being Indian." Custom does not equal culture. An overemphasis on custom, especially "traditional" custom, denys contemporary Americans multicultural competence. The cultural alternative for which multiculturalism might strive is the situation where it is culturally logical to be both a Sioux and a banker as well as Jewish and a cowboy.

An ethnological critique of cultural pluralism and the plural society suggests that multicultural teaching and learning strive toward a sociocultural reality of balanced cultural alternatives. Multiculturalism must allow individuals to optimize and maximize a vast array of cultural resources. True multiculturalism is the cultural freedom to, at will, participate in many cultures-each having equal access to socially valued and strategic resources. In and of itself though, multiculturalism cannot solve the structural inequalities of pluralism (Lewis, 1976). Only with the sterilization of racism and cultural imperialism will a true multicultural society emerge. Multiculturalism though, can act so as to foster, it not social, then cultural democracy.

The ethnological perspective further yields a more inclusive view of the structure of American society and culture. For better or worse, anthropology reflects the reality of how we are related, under what circumstances, one to the other ... a and why. The United States is a swirl of differing cultural histories and traditions. There is no one "model" American. The United States is dominated by a national Anglo-Saxon-JudaeoChristian influence we term "American." The country is institutionally integrated (i.e., compulsory schooling), yet characterized by structural inequality. The ethnological record is again useful in suggesting that schools, in part, are institutionalized mechanisms for differentially enculturating subgroups into this national culture (Cohen, 1970). Culturally, schools seek to integrate a plural condition by transferring local, subcultural allegience to national, supralocal allegience. One pledges allegience to the United States - not to Burton Corners or Grandma Agnes. Vis-a-vis "Chinese," "Russian," or "African" national societies (themselves complex multicultural entities), we are all taught to be "American." Schools integrate as much as they segregate. At this level, we all become "model" Americans. logical to be both a Sioux and a banker as well as Jewish and a cowboy.

An ethnological critique of cultural pluralism and cultural entities), we are all taught to be "Ämeric Schools integrate as much as they segregate. At level, we all become "model" Americans.

Barry Stark photo, Northern Illinois University

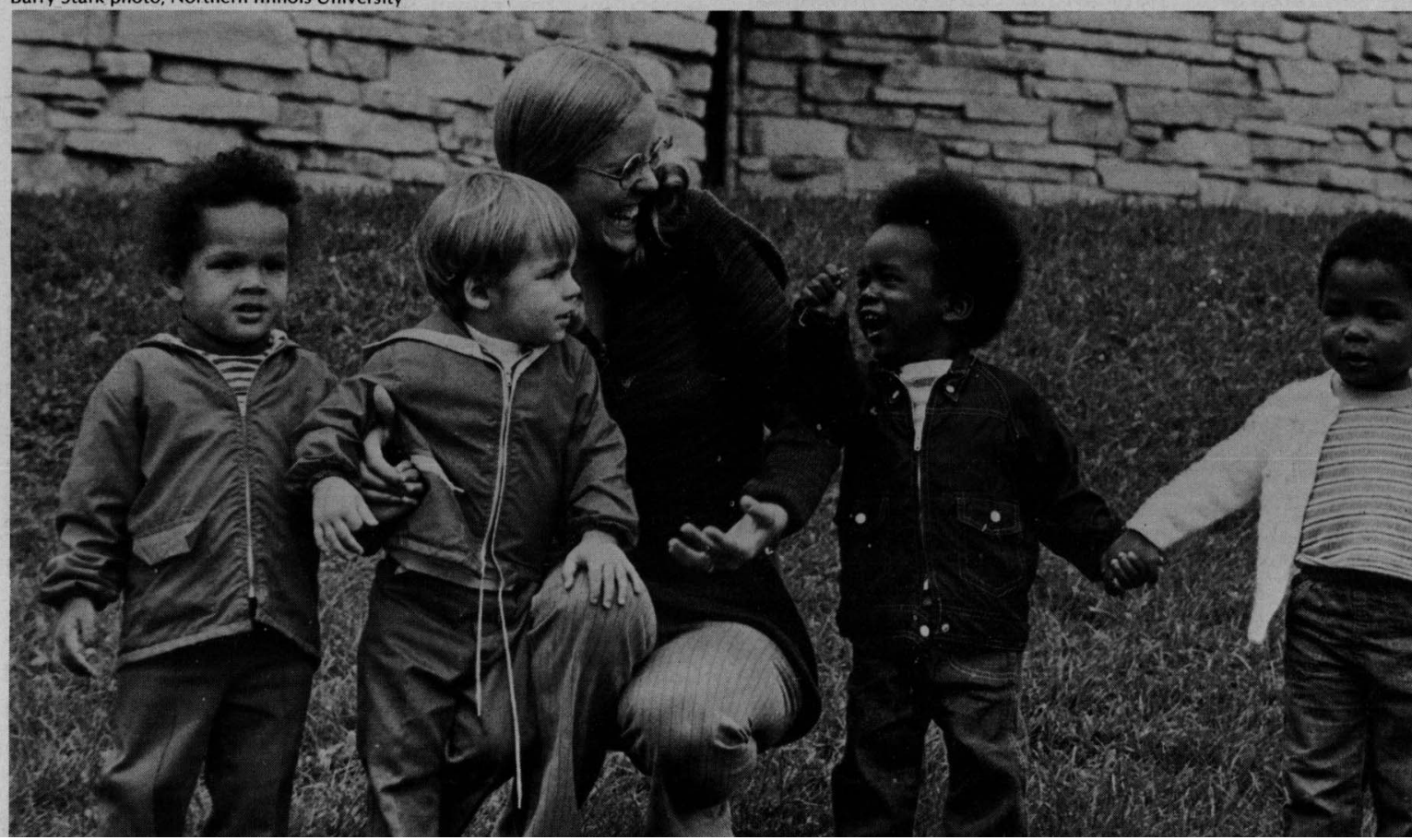




\section{Ethnography}

If the world is multicultural, then ethnographic anthropology is essential to a proper cultural understanding of the world. Ethnography anthropology is the sole discipline possessing descriptive, encompassing information on and accounts of the total lifeways for nearly all the peoples of the Earth. Ethnography provides multicultural teaching and learning with empirical information and materials on literally thousands of cultures and subcultures. The ethnographer is a cultural historian. The basic act of recording cultural ways fossilizes human alternatives for future generations. Ethnographic data is a prime resource for multicultural teaching and learning.

In several respects, learning to be a multicultural teacher (or learner) is quite similar to learning to become an ethnographer. As concerns preservice multicultural teacher training, the applied study of ethnographic field research methodology is of decided benefit (Bohannan, 1968). Ethnographers illustrate how to go about learning another culture (Burnett, 1974). To "learn" a culture means to internalize often unstated assumptions and rules for appropriate behavior; to "learn" a culture is to interpret and predict the behavior of others as well as to appropriately respond. The ethnographer is a professional cultural learner. As the ethnographer spends an extended period of time living the culture she/he seeks to understand, so too must the multicultural teacher and learner. It should not be enough to base cultural knowledge on several history, ethnic, or literature courses. Preservice multicultural teachers ought to be encouraged and supported to spend their practice-teaching year living in a culture or

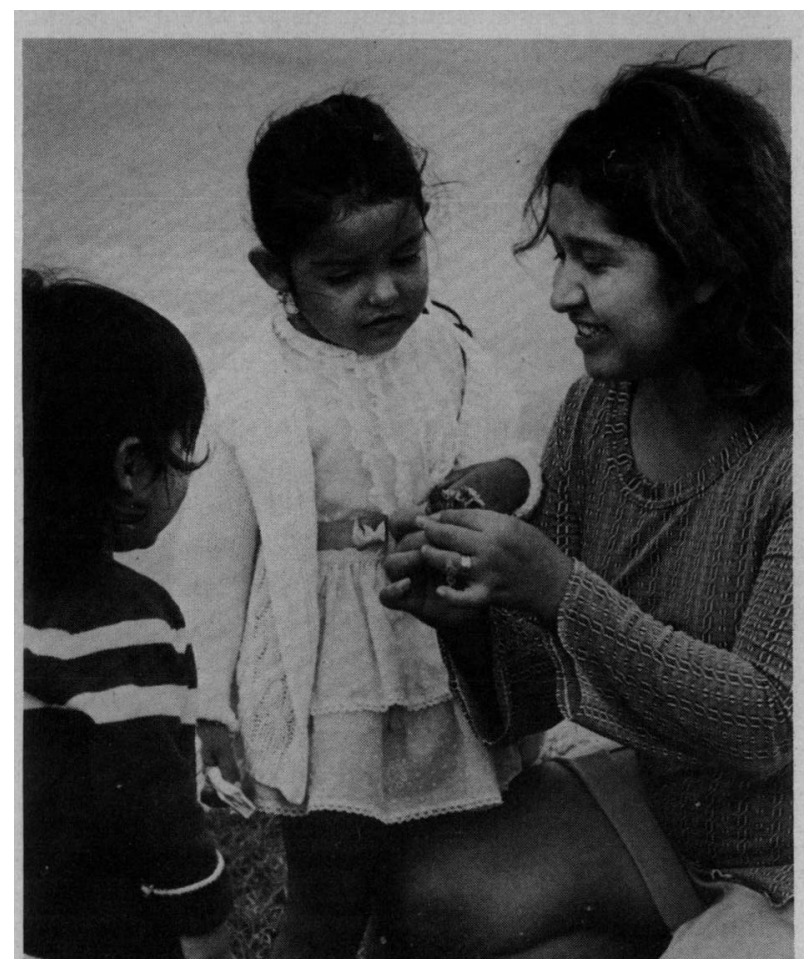

subculture different from their parent culture. The multicultural teacher might strive to entertain firsthand knowledge of the people and the culture(s) about whom she/he will teach primarily. Supported by their school systems or by federal funds, inservice multicultural teachers might spend a summer or two living in various cultural settings. Teachers might also take every advantage to know culturally the communities in which they teach. Through exchange programs, multicultural students might be encouraged to spend a period of time living in the teacher's subculture. Ethnography demands cultural involvement. Developed skills in cultural analysis makes possible the identification and understanding of significant cultural influences on specific classroom behaviors. As concerns the relative influence of family, peers, and community, the cultural learner establishes a wholistic, comparative perspective from which to apprehend the cultural interpretations given to teaching and learning (Eddy, 1968). Utilization of ethnographic research techniques teaches one how to learn another culture (Lundstrum, 1968).

Recently, educational anthropologists have given significant attention to the ethnographic study of schools and schooling (Johnson, 1976). In alliance with multicultural teachers, ethnographers can indicate the manner in which schools function to transmit, or not transmit, local cultural patterns. Ethnographers can suggest practical ways to reduce the "clash of cultures" in the multicultural classroom (Clark, 1963). Introductory, general anthropology ought to be a multicultural teacher education and inservice requirement. At the University of Michigan, I introduced a cross-listed course in Anthropology and Education. Centering on the ethnographic study of cross-cultural teaching and learning, the course gave preservice teachers a more inclusive perspective on which to base a conception and practice of education. The aim here is not to transform educators into ethnographers, but to engender a more effective multicultural teaching and learning. To this end, the multicultural teacher or learner must not just "do" multiculturalism; one must practice being multicultural.
Preservice multicultural teachers ought to be encouraged and supported to spend a year living in a culture or subculture different than their parent culture. They should strive to gain first-hand knowledge of the people and cultures about whom they will teach primarily.

Northern Illinois University photo by Barry Stark. 


\section{Linguistic Anthropology}

Linguistic anthropology considers the origin, structure, function, and significance of human symbolic communication. Language is the prime characteristic of being human. Symbolic communication is the means through which we learn to be human (socialization) as well as learn to be Hopi or German or Chicano (enculturation). Anthropological linguists search for the underlying universals in all languages as well as the more culture-specific variations of human communication. Anthropological linguists want to know how language is related to and expresses human similarity and difference. As human communication, all languages are of equal value and should be respected as such.

Attention to relevant data from anthropological linguistics provides multicultural teachers with a clearer conception of the relationship of language to culture. For each culture or subculture, language is the mechanism through which the world is ordered and invested with meaning. Language contains information as to the meaning of cultural behavior-to the meaning of cultural styles of teaching and learning. It is impossible to understand another culture without understanding their language. To participate in various cultures is, in part, to do so through language. Multilingualism is a reflex of multiculturalism.

For many school districts, the establishment of bilingual programs is federally mandated. For both teachers and learners, bilingualism is essential to multicultural communication and interaction.

Of course, multicultural students should be taught

No one person, "American" or otherwise, is a "model" or "average" representative of their culture. archeological anthropologist is concerned with reconstructing a knowledge of extinct human cultures, settlement patterns, and activity through the systematic study of material artifacts and remains (Thomas, 1974). Archeology extends out the time and space frame forming the unique perspective of anthropology; archeology contributes a knowledge of and respect for broad cultural patterns and processes of change and development. Archeological materials illustrate the cultural evolutionary sequences bringing about the origin and development of agriculture, towns, art, states, and complex civilizations.

Archeological materials validate claims concerning the multicultural reality of human history; they can be employed to depict the comparative contributions of various New World cultures to the development of North America in general and to the United States in particular. Archeology permits the placement of contemporary cultures within a wider spaciotemporal framework. Again, it can be seen that there is no one "model" America or American. Archeological anthropology provides the multicultural teacher and learner with tangible proof of multicultural contributions to the making of present-day America. As they can be seen and touched, archeological materials lend substance to the teacher's words. To hold in your hand a 900 year old potsherd is to realize the persistent reality of the past. Contemporary Chicano students might be apprised of the historic development and character of the Aztec and Toltec states in MesoAmerica. Contemporary Native Americans might be apprised of the relative importance of the Hohakam, Anasazi, and Hopewell cultures of a thousand years ago to the present character of America. As a counter to the prevalent dynamic of racism, Anglo students could be further sensitized to the high-order cultural contributions of other Americans (Citron, 1972). In fact as well as word, archeological anthropology suggests that there is indeed no one "model" American.

\section{Biological Anthropology}

Human beings are biological as well as cultural animals. Biological anthropology is concerned with documenting and understanding the physical nature and over four million year development of human beings as homo sapiens; of human beings as an animal species among other animal species (Campbell, 1976). Biological anthropologists seek the genetic causes of human similarity and difference.

An anthropological conception of "race" and racism is crucial to multicultural teaching and learning. Biological anthropology suggests that there is no such thing as "race." Phenotypic variation in skin coloring or hair texture varies with respect to environment, geographic history, and more recently, with politics. Again, subgroups in plural societies are often politically 
stratified by "race." The social conception of "race" allows one social segment to dominate other segments. Biologically, the only "race" is the human race. "Races" are merely intraspecies genetic breeding pools. In terms of being human, "race" (phenotypic variation) is of little consequence. Both morphological and phenotypic variations between individuals (say, you or your brother) are vastly greater than morphological or phenotypic differences between populations. As is popularly thought, phenotypic variation is not due to the differential presence or absence of particular genes; all human beings have 46 chromosomes. No human being is "subhuman." Human variation is due both to natural and cultural selection for particular combinations of genes. Human variation merely marks varying frequencies of gene combinations among dispersed populations.

For our species, population variation has adaptative consequences. Biologically and culturally, it is quite dangerous to try to make all peoples alike. Genetic variation, and the potential for variation, allows our species to adapt to widely differing environments. $A$ radical change in one environment will not affect the survival of the species. Biologically and culturally, human variability should be desired and valued as it broadens the "pool" from which adaptations to as yet unforseen future environments will be made. Both biologically and culturally, it is quite important that multicultural teachers and learners understand and appreciate how and why people are, at once, similar yet different.

Racism is the institutionalized belief that phenotypic characteristics determine cultural characteristics and behavior. Popular conceptions of "race" are based on sociocultural, economic, and political exigencies rather than on scientific fact; one should always distinguish popular from scientific criteria for the study of human variation (Marshall, 1968). Biology and culture are distinct, though related, mechanisms; the way a person looks does not determine their culture! Much of the history of biological anthropology reflects the continuing effort to clarify scientifically the causes of human variation. An abiding consideration of certain principles and data better enables multicultural teachers and learners to resist artificial arguments concerning I.Q., "race," and intelligence. Through the celebration of human diversity, both anthropology and multicultural education demonstrate a deep commitment to the continuing struggle against racism and cultural imperialism.

\section{References}

Dwyer-Schick, Susan. The Study and Teaching of Anthropology: An Annotated Bibliography. Athens: Anthropology Curriculum Project, publication \#76-1. University of Georgia, 1976.

Dynneson, Thomas. Pre-Collegiate Anthropology: Trends and Materials. Athens: Anthropology Curriculum Project, publication \#75-1. University of Georgia, 1975.

Williams, Thomas Rhys. Field Methods in the Study of Culture. New York: Holt, Rinehart, and Winston, 1967.

Ogbu, John. The Next Generation: An Ethnography of Education in an Urban Neighborhood. New York: Academic Press, 1974.

Goodenough, Ward. "Multiculturalism as the Normal Human Experience." Anthropology and Education Quarterly 7, no. 4 (1976): 4-6.

Lewis, Diane K. "The Multicultural Education Model and Minorities: Some Reservations." Anthropology and Education Quarterly 7, no. 4 (1976): 32-37.

Cohen, Yehudi. "Schools and Civilizational States." In The Social Sciences and the Comparative Study of Educational Systems, ed. by Joseph Fischer. Scranton: International Textbook Company, 1970, pp. 55-147.

Bohannan, Paul J. "Field Anthropologists and Classroom Teachers." Social Education 32, no. 2 (1968): 161-66.

Burnett, Jacquetta Hill. 1974. "On the Analog Between Culture Acquisition and Ethnographic Method." Council on Anthropology and Education Quarterly 5(1): 25-29.

Eddy, Elizabeth M. "Anthropology and Teacher Education." Human Organization 27, no. 1 (1958): 17-20.

Lundstrum, John P. "Anthropology: Preservice Teacher Education and Certification." Social Education 32, no. 2 (1968): 135-41.

Johnson, Norris Brock. An Ethnographic and Longitudinal Methodology for the Description and Illustration of Schooling as Cultural Transmission. Unpublished Ph.D dissertation, Department of Anthropology, University of Michigan. Ann Arbor: University Microfilms, 1976.

Clark, Kenneth B. 1963. "Clash of Cultures in the Classroom." Integrated Education 1(4): 7-14.

Labov, William. The Study of Nonstandard English. Champaign: National Council of Teachers of English, 1970.

Thomas, David Hurst. Predicting the Past: An Introduction to Anthropological Archeology. New York: Holt, Rinehart, and Winston, 1974.

Citron, Abraham. "White Students and the Multiethnic Curriculum." In Proceedings of a Conference on Multiethnic Curriculum and the Changing Role of the Teacher. ed. by Charles D. Moody, et al. Ann Arbor: University of Michigan School of Education, Program for Educational Opportunity, 1972.

Campbell, Bernard. Humankind Emerging. Boston: Little, Brown, and Company, 1976.

Marshall, Gloria (Niara Sudarkasa). "Racial Classification: Popular and Scientific." In Science and the Concept of Race, ed. by Margaret Mead, et al. New York: Columbia University Press, 1968, pp 147-64. 